\title{
Heffron $v$. International Society for Krishna Consciousness, Inc.: Confusing Free Speech with Free Exercise Rights
}

In Heffron v. International Society for Krishna Consciousness, Inc. , the United States Supreme Court held that a rule requiring the International Society for Krishna Consciousness (ISKCON) to distribute and sell hiterature and solicit contributions only froin a stationary booth within a state fairground was constitutional even though the rule inhibited rehgious practice. The rule was justified by the substantial state imterest in managing the flow of traffic at the fair. While an exemption froin the rule based on the free exercise clause of the first ainendment ${ }^{2}$ for ISKCON members alone would have caused ininimal congestion, the Court held that ISKCON had no greater claim to constitutional protection for distributing and selling literature or solicitimg contributions than groups with other religious, social, political, or ideological messages. Thus, an exeinption could not be limited to ISKCON. The Court therefore refused to declare the rule invahd, finding that to do so would result in extreine congestion at the fairground.

This Note argues that the Court took the wrong approach in Heffron when it denied an exemption for ISKCON. The Court should not have equated ISKCON's free exercise rights with the free speech rights of secular groups at the fair. Free speech and free exercise are not identical rights. The Court has formulated very different tests to consider whether they may be justifiably restricted.

In Part I, this Note summarizes the facts and holding of Heffron. Part II explores the legal background of the decision, paying particular attention to the Court's different ways of treating free speech and free exercise claims. Part III analyzes the Court's decision. First it applies to Heffron the traditional test uscd to analyze free exercise claims for legal exemptions. Next, it comparcs that outcome to the Court's analysis of time, place, and inanner restrictions on speech. The Note concludes that a free exercise claim protects the rights of ISKCON

1. 452 U.S. 640 (1981).

2. The first amendment to the United States Constitution provides that "Congress shall make no law ... prohibiting the free exercise [of religion]; or abridging the frcedoin of spcech . . . U. U.S. ConsT. amend. I. The Court has held that in some cases the free exercise clause requires exemption for religious groups from otherwise valid laws that restrict religious practice. See infra notes 56-74 and accompanying text. 
members more effectively than a free speech claim. The Court, therefore, should not have diluted the free exercise rights of ISKCON members by measuring them against the free speech rights of other fair participants.

\section{The Case}

ISKCON is an imternational religious society that adheres to Krishna doctrine. ${ }^{3}$ A central tenet of the religion is the practice of Sankirtan, which requires that members go into public places to distribute religious literature and solicit donations for the support of their religion. ${ }^{4}$ The Krishnas claim that Sankirtan is more than mere proselytizing: they claim to have ritualized the practice so that performance of Sankirtan is itself a religious practice more akin to prayer or ceremony than to the distribution of handbills. ${ }^{5}$ The fierce persistence with which ISKCON members practice Sankirtan las frequently made thein a public aimoyance. ${ }^{6}$

The Minnesota Agricultural Society promulgated rules governing the 1977 Minnesota State Fair. Rule 6.05 limited the sale or distribution of any merchandise, imcluding literature, to stationary booths within the fairgrounds. ${ }^{7}$ The rule did not, however, restrict visitors froin walking throughout the fairground to discuss their views.

ISKCON challenged rule 6.05 the day before the opening of the

3. ISKCON falls under the broad theological umbrella of the Vaishnava tradition of Bhakti Himduism, formalized in the ninth century in Southern India. The Krishna movement came to the United States in the mid-1960's. American members of ISKCON surrender their material possessions and change their diet, lifestyle, and physical appearance. International Soc'y for Krishna Consciousness, Inc. v. Barber, 650 F.2d 430, 433 (2d Cir. 1981).

4. For a discussion of the importance of Sankirtan to ISKCON members, see infra note 109 and accompanying text. Sankirtan is performed particularly aggressively in the United States. See Barber, 650 F.2d at 434.

5. See, e.g., 12 CuM. L. Rev. 693, 694 n.8 (1982).

6. One judge has called the Krishnas "experienced 'thieves' . . . under the 'cloak' . . . of being a religion" who pursue an "anti-social" course of behavior. International Soc'y for Krishna Consciousness, Inc. v. Barber, 506 F. Supp. 147, 169, 171 (N.D.N.Y. 1980), rev'd, 650 F.2d 430 (2d Cir. 1981). Not surprisingly, ISKCON has regularly sparked considerable conflict with unsympathetic state officials. See, e.g., Edwards v. Maryland State Fair \& Agricultural Soc'y, Inc., 628 F.2d 282, 285 n.2 (4th Cir. 1980); International Soc'y for Krishna Consciousness v. State Fair, 461 F. Supp. 719, 720-21 (N.D. Tex. 1978).

7. Rule 6.05 provided that the "[s]ale or distribution of any merchandise, including printed or written material except under license issued [by the Agricultural Society] and/or from a dulylicensed location shall be a misdemeanor." Heffron, 452 U.S. at 643. Similar regulations have been upheld at airports, see, e.g., International Soc'y for Krishna Cousciousness v. Eaves, 601 F.2d 809, 826-30 (5th Cir. 1979), but the state fair is not equivalent im character to an airport. See International Soc'y for Krishna Cousciousness, Inc. v. Heffron, 299 N.W.2d 79, 84 n.I0 (Minn. 1980) (en banc), rev'd, 452 U.S. 640 (1981); International Soc'y for Krishna Consciousness, Inc. v. Colorado State Fair \& Indus. Exposition Comm'n, 610 P.2d 486, 489 (Colo. 1980) (en banc). 
1977 state fair. It claimed that the rule, by inhibiting the practice of Sankirtan, violated the free exercise and free speech rights of ISKCON 1neinbers. ${ }^{8}$ The state asserted that the rule served the important interest of maintaining order at the fair and was neutrally enforced against all participants.

The Minnesota Supreme Court held that the rule violated ISKCON's free exercise rights ${ }^{9}$ and that ISKCON had a special claim to an exeinption on free exercise grounds. ${ }^{10}$ To justify rule 6.05 , the state had to do unore than identify the generalized harm to which the rule was directed. Its burden was to establisl the important state interest in avoiding the specific disorder that would result if ISKCON alone were granted an exemption. This the state could not do. ${ }^{11}$

The United States Supreine Court reversed. Although the Court recognized that the first amendment protects distribution of religious materials and solicitation of contributions, it regarded these activities as subject to reasonable time, place, and inanner restrictions. ${ }^{12}$ Seen in these terms, the issue was whether the Minnesota rule was a reasonable restriction. ${ }^{13}$ The Court found that the rule satisfied the requirements that it not be based on the content of the speech, ${ }^{14}$ and that it not be susceptible to arbitrary enforcement. ${ }^{15}$ The Court also found that no alternative nieans less restrictive of first ainendment rights could deal adequately with the probleins created by Sankirtan, ${ }^{16}$ and that alternative arenas for its practice were available. ${ }^{17}$ Finally, the Court accepted the state's assertion that the rule was needed to inaintain the orderly moveinent of the crowd at the fair. ${ }^{18}$

8. ISKCON's complaint, filed under 42 U.S.C. \& 1983 (1976) and MINN. STAT. ANN. $\S 555.01$ (West Supp. 1981), alleged a violation of both the free speech and free exercise clauses of the first amendment. ISKCON subsequently dropped its free exercise claim. See Heffron, 452 U.S. at $659 \mathrm{n} .3$ (Brennan, J., concurring in part and dissenting in part); Transcript of Oral Argument at 25-26, Heffron (No. 80-795); Brief for Respondent at 8, 19-20, 47-48, Heffron (No. 80-795); Note, Heffron v. ISKCON: The Tenuous Touchstone-A Step In The Wrong Direction?, 19 Hous. L. REv. 325, $331-32$ (1982). The majority nonetheless decided the issue of whether ISKCON was entitled to a religious exemption. Heffron, 452 U.S. at 659 n.3 (Brennan, J., concurring in part and dissenting in part).

9. International Soc'y for Krishna Consciousness, Inc. v. Heffron, 299 N.W.2d 79, 81 (Minn. 1980), rev'd, 452 U.S. 640 (1981).

10. $I d$. at $83 \mathrm{n} .7$.

11. Id. at 83-84.

12. Heffron, 452 U.S. at 647 .

13. Id. at 648.

14. Id. at $648-49$.

15. Id. at 649.

16. Id. at 654 .

I7. Id. at 654-55. The Court also found that the rule had not been shown to deny all access within the forum. Id. at 655 .

18. Id. at 654 . The Court did not reach the two other asserted state interests: protecting citizens from fraudulent solicitation, and protecting them from being harassed. Id. at $650 \mathrm{n} .13$. 
The Court found that ISKCON had no claim to first amendment protection superior to that of other religious groups distributing literature and soliciting contributions, but not purporting to ritualize the process. ${ }^{19}$ The Court held that if the rule were invahid with respect to ISKCON, it would be "no more valid" with respect to the nonreligious groups at the fair. ${ }^{20}$ ISKCON's exemption would inandate giving all groups permission to distribute and solicit freely throughout the fairground. The resulting disorder would be great. ${ }^{21}$ Thus, the Court held that the state's interest im crowd control justified the regulation, and that rule 6.05 did not violate the first amendment. ${ }^{22}$

In his concurrence and dissent, Justice Brennan maintained that the majority erred in not analyzing separately the three types of activities involved: distribution of literature, sale of literature, and solicitation of funds. ${ }^{23}$ Protecting the public from fraud, Justice Brennan argued, justified the restriction on sales and solicitation. This, however, did not justify the fair's restriction on distribution of free literature. ${ }^{24}$ The state had not shown that distributing hiterature would add any more disorder than could result froin speeches and face-to-face proselytizimg by fair participants. ${ }^{25}$ Justice Brennan also asserted that the Court "disparage[d] the significance" of Sankirtan ${ }^{26}$ by refusing to distinguish between the many religious groups who solicit contributions and distribute literature and the few for which it is a religious ritual or practice. ${ }^{27}$ For groups such as ISKCON, for which the activities are a ritual, the prior free exercise cases require that any restriction should be scrutinized with particular care. ${ }^{28}$ In Justice Brennan's view, the Court held that even if Sankirtan was conduct protected by the free exercise clause, it was entitled to no greater protection than other forms of expression protected by the free speech clause. ${ }^{29}$
19. Id. at 652 .
20. Id. at 653 .
21. Id.
22. Id. at 654.
23. Id. at 656 (Brennan, J., concurring in part and disseuting in part).
24. Id. at 657.

25. Id. at 661 . Justice Brennan also argued that the ordinance could be drawn more uarrowly without undermining the state's interest in crowd control. Id. at 663 .

26. Id. at 659 n.3. He noted that because ISKCON claimed no special rights because of Sankirtan and was willing to rest on the general right to free speech, see supra note 8, there was no nced for the Court to discuss Sankirtan. 452 U.S. at 659 n.3.

27. 452 U.S. at 659 n.3.

28. Id.

29. Id. This Note also assumes that this is the Court's holding. Several commentators have supported Justice Brennan's view of the case. See, e.g., Note, Continued Erosion of a Fundamental Right: Heffron v. International Society for Krishna Consciousuess, Inc., 9 FlA. ST. U.L. Rev. 682 (1981); Note, Heffron v. Internatioual Society for Krishna Consciousness, Inc.: Reasonable Time, Place and Manner Restrictions, 15 J. MAR. L. REv. 543 (1982); Note, Heffron v. International 
II

\section{LEGAL BACKGROUND}

\section{A. First Amendment Protection for Proselytizing}

The solicitation and distribution activities involved in Heffron are protected by the first annendment. ${ }^{30}$ Distribution of literature is protected by the free speech clause, ${ }^{31}$ while distribution of religious tracts enjoys the added protection of the free exercise clause. ${ }^{32}$ Literature that is sold rather than given away is still protected by both clauses. ${ }^{33}$ The free speech and free exercise clauses also protect solicitation for contributions by religious groups. ${ }^{34}$ The constitutional protection afforded these activities, however, is not unlimited. A state inay subject these activities to reasonable regulation when a sufficiently important state interest is at stake. ${ }^{35}$

Society for Krishna Consciousness, Inc: A Restrictive Constitutional View of the Proselytizing Rights of Religious Organizations, 9 PEPPERdINE L. REv. 5 I9 (1982).

In his concurrence and dissent, Justice Blackmun stated that he too would not reach the question of whether ISKCON was entitled to an exemption based on Sankirtan. Id. at $663 \mathrm{n} .1$ (Blackmun, J., concurring in part and dissenting in part). He agreed that, for the reasons stated by Justice Brennan, the rule was unconstitutional as applied to the distribution of literature. Id. at 663. He argued, however, that the restriction on sales and solicitations was justified by the state's interest in crowd control. Id. at 665 .

30. See International Soc'y for Krishna Consciousness, Inc. v. Rochford, 425 F. Supp. 734, 739 (N.D. Ill. 1977), affd in part and rev'd and remanded in part, 585 F.2d 263 (7th Cir. 1978) (citing Murdock v. Pennsylvania, 319 U.S. 105 (1943), and lnternational Soc'y for Krishna Consciousness, Inc. v. City of New Orleans, 347 F. Supp. 945 (E.D. La. 1972)).

31. See Schneider v. State, 308 U.S. 147, 160 (1939) (Constitution protects right to speak, write, print, and circulate information); Lovell v. City of Griffin, 303 U.S. 444, 452 (1938) (free speech and press rights protect distribution as well as publication).

32. Murdock v. Pennsylvania, 319 U.S. 105, $108-09$ (1943) (hand distribution of religious tracts is an age-old form of evangehsin that "occupies the saine high estate" under the free exercise clause as worship in the church and preaching from the pulpit, and has the same claim to protection as more orthodox religious exercises).

33. Id. at 111. See also Jannison v. Texas, 318 U.S. 413, 416-17 (1943) (state may not prohibit distribution of handbills on city streets in pursuit of religious activity merely because handbills solicit purchases of literature and contributions for religious purposes).

34. Village of Schaumburg v. Citizens for a Better Env't, 444 U.S. 620, 633 (1980) (charitable sohcitations are protected by free speech clause); Murdock, 319 U.S. at 111 (distribution of handbills by religious group protected even though it involves an appeal for contribution); Cantwell $v$. Connecticut, 310 U.S. 296, 305 (1940) (ordinance prohibiting solicitation without approval by public welfare council unconstitutional because it allows too inuch discretion and censorship of certain rehigions).

35. E.g. , Breard v. City of Alexandria, 341 U.S. 622, 642-43 (1951) (first amendment never treated as an absolute); Contwell, 310 U.S. at 304 (religious conduct subject to reasonable regulations). A claim of rehgious freedom obviously does not exempt even rehgious ritual from state scrutiny where an important state interest is at stake. See, e.g., State v. Massey, 229 N.C. 734, 51 S.E.2d 179 (upholding North Carohina law prohibiting the handhing of poisonous snakes in religious ceremony), appeal dismissed per curiam sub nom. Bunn v. North Carohina, 336 U.S. 942 (1949). But cf. State v. Whittingham, 19 Ariz. App. 27, 504 P.2d 950 (1973) (exemption from penal prohibition against the use of peyote in religious ceremony), petition for review denied, 110 Ariz. 279, 517 P.2d 1275, cert. denied, 417 U.S. 946 (1974); People v. Woody, 61 Cal. 2d 716, 394 P.2d 


\section{B. The Court's Different Treatment of Religion and Speech}

The Court has generally treated claims under the religion and speech clauses differently. Only once, ${ }^{36}$ nearly forty years before $\mathrm{Hef}$ fron, did the majority assert that speech and religion are equally protected rights. In that case, Massachusetts convicted a Jehovah's Witness of violating state child labor laws ${ }^{37}$ by allowing lier niece to distribute cluurch tracts. ${ }^{38}$ Conceding that the state could restrict her conduct without violating the free speech clause, the claimant argued that the free exercise clause offered greater protection agaimst state interference. ${ }^{39}$ The Court rejected the claim, stating that no liberty protected by the first aunendment is favored over another. ${ }^{40}$

The Court has analyzed other cases involving possible claims under both the free speech and free exercise clauses on eitler speech or religion grounds alone, witlout explaining why one clause was chosen over the other. Typically, though not always, these cases liave been decided only on speecli grounds. ${ }^{41}$

In cases mvolving speech or religion alone, the Court has treated freedom of speecli and freedom of religion as very different riglits. A portion of the Court's analysis in Buckley v. Valeo, ${ }^{42}$ the case reviewing the constitutionality of the 1974 amendments $^{43}$ to the federal election laws, ${ }^{44}$ illustrates soine of these differences. The Court traditionally has held that the first aunendment's establishment clause requires Con-

813, 40 Cal. Rptr. 69 (1964) (same). For a hypothetical case imvolving a claimed exemption for the ritual sacrifice of a human being set in the year 2383, see Pepper, The Case of the Human Sacrifice, 23 ARIz. L. REv. 897 (1981).

36. See Prince v. Massachusetts, 321 U.S. 158, 164-65 (1944).

37. For the current version of the challenged laws, see Mass. GEN. LAwS ANN. ch. 149, $\S \S 80-81$ (West 1982).

38. 321 U.S. at 160.

39. See id. at 164 .

40. Id. at 164-65.

41. See, e.g., Widmar v. Vincent, 454 U.S. 263, 277 (1981) (university policy denying student religious group access to university facilities in order to meet and worship challenged on speech and religion grounds, held unconstitutional only on speech grounds); Wooley v. Maynard, 430 U.S. 705 (1977) (requirement that license plates be embossed with New Hampshire state motto "Live Free or Die" challenged on both free speech and free exercise grounds but invalidated on free speech grounds alone); Martin v. City of Struthers, 319 U.S. 141 (1943) (ordinance prohibiting knocking on doors while distributing information was invahdated on free speech grounds with no reference to defendant's free exercise claim); Lovell v. City of Griffin, 303 U.S. 444 (1938) (no inention of free exercise in upholding Jehovah's Witnesses' challenge to ordinance restricting distribution of literature). But see, e.g., Cantwell v. Counecticut, 310 U.S. 296 (1940) (ordmance requiring that public official certify that solicitor represents a religious cause was challenged on both free speech and free exercise grounds, but invalidated on free exercise grounds alone).

42. 424 U.S. 1 (1976) (per curiam).

43. Federal Election Campaign Act Amendinents of 1974, Pub. L. No. 93-443, 88 Stat. 1263 (codified in scattered sections of 2, 5, 18, 26 \& 47 U.S.C. (1976)).

44. Federal Election Campaign Act of 1971, Pub. L. No. 92-225, 86 Stat. 3 (1972) (codified in scattered sections of $2,18 \& 46$ U.S.C. (1976)). 
gress to remain neutral in religious inatters, and prohibits the state from aiding or inhibiting any particular religion or even all religions equally. ${ }^{45}$ Similarly, the Court has leeld that in controversies within a clurch, courts slould "defer to the resolution of issues of religious doctrine or polity by the highest court of a hierarchical churcli organization." 46 By analogy to these religion cases, appellants in Buckley cliallenged the public funding aspects of the federal law. ${ }^{47}$ They asserted that "the similarities between partisan politics and religion are so great that the same concerns that protect religious liberty should also protect political liberty"; therefore the state should avoid entanglement in political activity. ${ }^{48}$ Appellants argued that public funding would lead to state control of the internal affairs of political parties, and thus to a loss of political freedom. ${ }^{49}$

The Buckley Court quickly rejected these arguments. ${ }^{50}$ The Court anaintained that while government inay not aid in the exercise of religion, Congress inay provide "financial assistance to the exercise of free speecl.""51 The Court felt this different treatment was consistent with the "markedly different" "historical bases" of the religion and speech clauses. ${ }^{52}$ While government aid to religious groups is generally contrary to the goals of the religion clauses, ${ }^{53}$ government aid to speech activities furthers the purpose of the free.speech clause. ${ }^{54}$ In addition, the Court stated, government may involve itself in the internal affairs of political parties and other groups engaging in speech activities, ${ }^{55}$ notwithstanding court deference to the internal affairs of churcl organizations. Thus, the Court would not extend to speech groups the hands-off treatinent religious groups received.

45. E.g., School Dist. v. Schempp, 374 U.S. 203, 222-26 (1963); Everson v. Board of Educ., 330 U.S. 1, 15-16 (1947).

46. Jones v. Wolf, 443 U.S. 595, 602 (1979) (dispute over church property). See also Serbian E. Orthodox Diocese for the United States \& Canada v. Milivojevich, 426 U.S. 696 (1976) (dispute over whether individual is a church official). See generally Ellman, Driven from the Tribunal: Judicial Resolution of Internal Church Disputes, 69 CALIF. L. REv. 1378 (1981).

47. Federal Election Campaign Act Amendments of 1974, Pub. L. No. 93-443, \$§ 403-408, 88 Stat. 1263, $1291-303$ (codified as amended in scattered sections of 26 U.S.C. (1976)).

48. See Reply Brief for Appellants at 55-56, Buckley (No. 75-436), quoted in Polsby, Buckley v. Valeo: The Special Nature of Political Speech, 1976 Sup. CT. REv. 1, 32-33.

49. Buckley, 424 U.S. at 93 n.126.

50. Id. at $92-93$.

51. Id. at 93 n. 127.

52. Id.

53. See generally Note, California Teachers Association v. Riles: Textbook Loans to Sectar. ian Schools, 70 CALIF. L. REv. 959, 964-67 (1982).

54. Buckley, 424 U.S. at 93 n.127.

55. Id. at 93 . 


\section{The Free Exercise Test}

\section{Constitutionally Required Exemptions: Cases and Test}

Another difference between rehgion and speech claims is the remedy provided. Courts grant a unique exemption to religious claimants whose practices would be restricted by otherwise valid regulations. A successful free exercise challenge produces a valid regulation enforceable against all persons except those conipelled by their religion to violate the regulation. ${ }^{56}$ In contrast, a successful free speech challenge invalidates the entire restrictive portion of the regulation, "enforcement of [which] . . . is totally forbidden" against any group. ${ }^{57}$ The exemption provision is unique to free exercise claims.

Three Suprenie Court cases laid the groundwork for granting free exercise exeinptions. In Sherbert $v$. Verner ${ }^{58}$ a Seventh-Day Adventist was denied uneinployment benefits because she refused to work on Saturday, the Sabbath for niembers of her religion. The Court found that the denial of benefits placed a burden on her free exercise rights. ${ }^{59} \mathrm{Be}-$ cause the state could not show that exempting Seventh-Day Adventists froin the statutory schenie would defeat its asserted state imterest, ${ }^{60}$ the Court granted an exeniption. ${ }^{61}$

In Thomas v. Review Board, ${ }^{62}$ the plamtiff, who quit his job when he was transferred to a conipany division producing turrets for tanks, claimed that his religious beliefs prohibited him front performing such work. Subsequently, he was denied uneinployment benefits on the grounds that his termination was not for "good cause" as defined by the Indiana uneinployment statute. The Court granted the exemption, ${ }^{63}$ holding that his decision not to work was nrade for rehgious reasons, and that the infringement of his rehgious rights was not justified by a conpelling state interest. ${ }^{64}$

In the third case, Wisconsin v. Yoder, ${ }^{65}$ Amish parents defended their refusal to send their children to school beyond the eighth grade on the grounds that attendance was contrary to their religion. The Court held that the attendance requirenent interfered with the free exercise

56. See L. Tribe, AMERICan Constitutional LAW § 14-4, at 821 (1978).

57. Broadrick v. Oklahoma, 413 U.S. 601,613 (1973).

58. 374 U.S. 398 (1963).

59. Id. at 403. The Court thus recognized for the first time that an indirect burden on religious practice can implicate the first amendment. Id. at 404.

60. The State argued that denying benefits would discourage spurious future claims and avoid depletion of available state funds. Id. at 407 .

61. Id. at $406-09$.

62. 450 U.S. 707 (1981).

63. Id. at 719 .

64. Id. at 714-15, 719 .

65. 406 U.S. 205 (1972). 
of religion. ${ }^{66}$ Lacking a demonstration by the state that a special rule for the Amish children would impede the state's objective of universal education, ${ }^{67}$ the Court granted the exemption. ${ }^{68}$

In the Sherbert-Yoder-Thomas line of cases, the Court formulated a balancing test ${ }^{69}$ for analyzing free exercise claims for exemption. ${ }^{70}$ The analysis begms with whether the restricted practice is "religious." Religious activities are very liberally defined. ${ }^{71}$ The Court then considers the nature and degree of the restriction and whether the state can justify it ${ }^{72}$ Acceptable justifications are rare. First, only state interests of the "highest order" will support such restrictions. ${ }^{73}$ Second, the Court's focus in these cases is narrow. A state may not justify the rcgulation simply by showing that the regulation serves its general state interest; it must show that exempting the particular religious claimants would disrupt a specific regulatory scheme. ${ }^{74}$ As the size of the affected

66. Id. at 219-21.

67. Id. at 221.

68. Id. at 234.

The Court in these cases quickly dismissed the notion that such accommodation is a violation of the establishment clause. See id. at 220-21 (danger that accommodation may run afoul of establishment clause cannot prevent all exceptions no matter how vital to protection of free exercise rights, and Court must flexibly apply the two clauses); Sherbert, 374 U.S. at 409 (accommodation is neutral and does not involve interference of the secular in religious affairs). See generally Walz v. Tax Comm'n, 397 U.S. 664, 668-69 (1970); L. TRIBE, supra note 56, § 14-4, at 819-23; Moore, The Supreme Court and the Relationship Between the "Establishment" and "Free Exercise" Clauses, 42 TEX. L. REv. 142, 194-95 (1963).

69. See Giannella, Religious Liberty, Nonestablishment, and Doctrinal Development (pt. 1), 80 HARV. L. REV. 1381, 1390 (1967) (describing a "thoroughgoing balancing test" in the exemption cases); Note, Religious Exemptions Under the Free Exercise Clause: A Model of Competing Authorities, 90 Y ALE L.J. 350, 355 (1980) (a rough composite test has emerged in exeinption cases).

70. These exemptions are available only to religious claimants; had the cases been brought under the free speech clause, the challenges would have failed. See M. MaLbin, ReLioion AND Politics: The INTENTIONS OF THE AUthors OF THE First AMENDMent 39 (1978) (im Sherbert and Yoder, Court held Constitution to require people who do things for religious reasons to be "treated differently from people who do the same things for other reasons"); Choper, Defining "Religion" in the First Amendment, 1982 U. ILL. L. REV. 579, 585 (the first amendment right to free speech would not have required that Sherbert receive unemployment compensation had she declined work in order to work two days a week organizing a political party; no exemption would have been granted had the Yoders taken their children out of school because they were needed to work on their mother's campaign for public office); Pfeffer, The Supremacy of Free Exercise, 61 GEO. L.J. 1115, 1140 (1973) (had Sherbert quit her job at a newspaper because she disagreed with its editorial slant, no unemployinent compensation); Saladin, Relative Ranking of the Preferred Freedoms: Religion and Speech, 1964 ReLIGION \& PUB. ORD. 149, 153 (no cases in which exemptions comparable to that in $S$ herbert were given for free speech purposes).

71. See Thomas, 450 U.S. at 715 (imitial question is whether claim is religious; unless "so bizarre," Court will accept the claim); Yoder, 406 U.S. at 215 (clain to exemption cannot be based on purely secular considerations). The simcerity of a religious practice is sometimes suspect when it is used as a cover for racial bias. See Pepper, infra note 89, at 290 n.119; infra notes 99-101 and accompanying text.

72. See infra notes 103-09 and accompanying text.

73. Yoder, 406 U.S. at 215. See infra notes $110-11$ and accompanying text.

74. See Yoder, 406 U.S. at 221; infra notes 112-21 and accompanying text. 
group shrinks, regulatory exemptions become less disruptive. The state may find it impossible to show that the system cannot bear making an exception for a small rehgious group.

\section{The History of the Free Exercise Test}

The judicial attitude reflected in the religious exemption test is of comparatively recent vintage. The Court's treatment of the free exercise clause can be divided roughly into three periods. The first period began with Reynolds $v$. United States, ${ }^{75}$ in which the Court held that a criminal statute prohibitimg polygamy could be applied to a Mormon who felt compelled by his religion to violate the law. The Court held that the free exercise clause deprived Congress of the power to restrict rehgious behef, but left Congress free to restrict religious behavior and action. ${ }^{76}$ Initially, therefore, rehgious practice was considered outside the protection of the first amendment. ${ }^{77}$

In the 1930's and 1940's, the Jehovah's Witnesses sued to overturn numerous ordinances restricting their ability to preach on the streets or in parks, to solicit contributions, and to distribute literature. Faced with these challenges, the Court in this second period retreated from the strict belief/action dichotomy of Reynolds ${ }^{78}$ and held that the free exercise clause provided at least some protection for religious activity. In Cantwell v. Connecticut, ${ }^{79}$ for example, the Court found free exercise to embrace two concepts- "freedom to believe and freedom to act."80 Modifymg Reynolds, the majority stated that the freedom to believe is absolute, ${ }^{81}$ and the freedom to act, though limited by the need for order in society, ${ }^{82}$ cannot be unduly infringed. ${ }^{83}$ Precisely what the Court meant by undue infringement was unclear, ${ }^{84}$ but judicial protection of rehgious activities in conflict with local laws remained limited through-

75. 98 U.S. 145 (1878).

76. Id. at 164 .

77. See also Late Corp. of the Church of Jesus Christ of Latter-Day Saints v. United States, 136 U.S. 1, $48-50$ (1890); Davis v. Beason, 133 U.S. 333 (1890).

78. The distinction between religious action and belief was never of nuch analytical value, because cases arose only when behefs impelled the devotee to act. See 17 STAN. L. REv. 494, 495 n.5 (1965).

79. 310 U.S. 296 (1940).

80. Id. at 303.

81. Although they are rare, some cases have understandably limited the "absolute" freedom to believe. See, e.g., Hollon v. Pierce, 257 Cal. App. 2d 468, 478-79, 64 Cal. Rptr. 808, 814-15 (1967) (when hiring school bus drivers, city may discriminate agamst applicants whose religion provides for the sacrificial killing of children).

82. Cantwell, 310 U.S. at 303-04.

83. Id. at 304.

84. See Pepper, Reynolds, Yoder, and Beyond: Alternatives for the Free Exercise Clause, 1981 UTAH L. REV. 309, 329-30. 
out this period. ${ }^{85}$

The second period lasted through 1961, when the Court, in Braunfeld v. Brown, ${ }^{86}$ held that a Sunday closing law could be applied to Orthodox Jews, who for religious reasons could not work on Saturdays and wanted to keep their places of business open on Sundays. Since the burden on the religious claimants was only economic and thus indirect, ${ }^{87}$ such a restriction would be valid unless it were shown that a less burdensome means could accomplisli the state's purpose. ${ }^{88}$

Beginning in 1963 with Sherbert $v$. Verner, and continuing to the present, ${ }^{89}$ the third doctrinal strand enlarged considerably protection under the free exercise clause. ${ }^{90}$ In Sherbert, the Court read the Constitution to require in soune cases that secular law give way to religiously compelled activity. ${ }^{91}$ Two factors characterize the present test: the great showing the State inust make in order to justify the restriction and the narrow focus of the Court's inquiry.

\section{The Speech Test}

Regulations that restrict the time, place, and maimer of speecl on a content-neutral basis are unore easily justified by the state than limitations on religious exercise. As a practical inatter, speecli restrictions are

85. See id. at 327 (no successful claim for relief exclusively under the free exercise clause until 1963); Pfeffer, supra note 70, at 1130 (free exercise during these years practically nonexistent). See, e.g., In re Summers, 325 U.S. 561 (1945) (qualified applicant who refused on religious grounds to serve in state militia if called denied admission to bar); United States v. Schwimmcr, 279 U.S. 644 (1929) (Quaker who refused to pledge to defend the U.S. denied naturalization), overruled by Girouard v. United States, 328 U.S. 61 (1946).

86. 366 U.S. 599 (1961).

87. Id. at $605-06$.

88. Id. at 607. Although Sunday closing laws have long been the subject of complaints, even by such early social novehists as Charles Dickeus, see Dickens, The Sabbath Laws, reprinted in The Portable Victorian Reader 324-27 (G. Haight ed. 1972), they have regularly. bcen upheld. See Gallagher v. Crown Kosher Mkt., 366 U.S. 617 (1961) (free exercise challenge); Two Guys froin Harrison-Allentown, Inc. v. McGinley, 366 U.S. 582 (1961) (establishment clause challenge); McGowan v. Maryland, 366 U.S. 420 (1961) (establishment clause challenge). Sorne states have statutorily exempted religious groups fron these Sunday "blue laws." See, e.g., Commnonwealth v. Arlan's Dep't Store, 357 S.W.2d 708 (Ky.), appeal dismissed per curiam, 371 U.S. 218 (1962); People v. Bellet, 99 Mich. 151, 57 N.W. 1094 (1894).

89. United States v. Lee, 455 U.S. 252 (1982), is the most rccent apphication of the test. in Lee, an Amish failed to comply with the social security tax law. He defended on the ground that the Amish beheve it a sin not to provide for their needy, that they are religiously opposed to a national social security system, and that imposition of the tax violated his free exercise rights. The Court denied an exeinption, finding that it would be impossible to limit the exemption to the Amish. Id. at 260. Lee is a straightforward application of the Sherbert-Yoder-Thomas test, and adds nothing new to the doctrine. See Pepper, The Conundrum of the Free Exercise Clause-Some Reflections on Recent Cases, 9 N. KY. L. REv. 265, 301 (1982). But cf. id. at 300 (Lee may also be viewed as a retreat from the Sherbert-Yoder-Thomas test).

90. See Pepper, supra note 84, at 331; Pfeffer, supra note 70, at 1139.

91. See, e.g., Sherbert, 374 U.S. at 402-03. 
valid provided the state can meet certain relatively simple requirements. ${ }^{92}$ Primarily, the government must show that some interest, alternatively characterized as "significant,"93 "sufficiently strong" and "subordmating,"94 or "important or substantial,"95 is served by the regulation. The state also must show that the regulation is enforced uniformly, without regard to speech content.

The scope of judicial mquiry into justifications offered by the state differs in the free exercise and free speech cases. In speech cases, procedural rules prohibitimg a party from challenging legislation as it applies to others not before the Court are disregarded to allow broad challenges to the facial validity of legislation. ${ }^{96}$ This exception is made in order to prevent a chilling effect on freedom of expression. ${ }^{97}$ Under traditional free speech doctrine, therefore, the Court may properly consider the rights of all possible speecl groups. In contrast, a court hearing a challenge based on free exercise doctrine should restrict its inquiry to the religious group before it and to others similarly situated.

\section{III}

\section{ANALYSIS}

\section{A. Equal Treatment of Speech and Religion: The Legacy of Heffron}

In Heffron v. International Society for Krishna Consciousness, Inc., the Supreme Court did not use the test articulated in Sherbert, Yoder, and Thomas to analyze the validity of the Krishnas' free exercise claim. Instead, it equated ISKCON's rights with the rights of other religious groups and with the free speech rights of secular groups. The Court felt it could not give the Krishnas an exemption without giving an exemption to other rehgious and secular groups at the fair. The Court then accepted the state's argunients that imtolerable disorder would result if all participants at the fair were free to distribute literature and solicit contributions outside of booths. ${ }^{98}$

The Court erred in equating ISKCON's free exercise claim with the speech rights of secular groups at the fair. The free speech and free exercise tests are different. A religious claimant such as ISKCON has greater protection under the free exercise clause than under the free

92. See, e.g., Virginia State Bd. of Pharmacy v. Virginia Citizens Consumer Council, Inc., 425 U.S. 748, 771 (1976); Grayned v. City of Rockford, 408 U.S. 104, 115-17 (1972); L. TRIBE, supra note $56, \S \S 12-20$ to -21 , at $682-93$.

93. E.g., Grayned, 408 U.S. at 115.

94. E.g., Schaumburg, 444 U.S. at 636.

95. United States v. O'Brien, 391 U.S. 367, 377 (1968).

96. E.g., Schaumburg, 444 U.S. at 634; Grayned, 408 U.S. at 114-15; Sedler, The Assertion of Constitutional Jus Tertii: $A$ Substantive Approach, 70 CALIF. L. Rev. 1308, 1326 (1982).

97. See Grayned, 408 U.S. at 114; Sedler, supra note 96, at 1326-27.

98. Heffron, 452 U.S. at 652-54. 
speech clause. The difference is illustrated by applying each test separately to the facts of Heffron.

\section{Applying the free exercise and speech tests to Heffron \\ a. Application of the free exercise test}

In determining whether a rehgious exemption is constitutionally required, the threshold question is whether the belief or practice is religious. ${ }^{99}$ The Krishnas' Sankirtan meets this minimum requirement. First, the Court has accepted liberally and with minimal scrutiny a claimant's characterization of an act or practice as rehgious. ${ }^{100}$ Indeed, as long as the claim is not "so bizarre, so clearly nonreligious in motivation," the Court will accept that the practice is religious. ${ }^{101}$ Performance of Sankirtan is not "so bizarre," and the parties in Heffron stipulated that meinbers of ISKCON have a unique rehigious duty to perform it. ${ }^{102}$ The Court had no reason to doubt that Sankirtan was a religious practice.

Once it has been established that a religious practice is involved, it is necessary to assess the nature and degree of the restriction on that practice. ${ }^{103}$ The more the challenged regulation restricts the religious practice and the more central the practice is to the rehgion, the inore suspect the regulation becomes. In Thomas v. Review Board, for exainple, the Court noted that the restriction on Thomas's religious practice was indirect but severe: ${ }^{104}$ the unemployment benefits rules did not directly state that Thomas inust work on war inaterials-only that if he quit for that reason, he would not receive unemployinent coinpensa-

99. See supra text accompanying notes 69-71; Thomas, 450 U.S. at 713 (only beliefs rooted in religion are protected by free exercise clause); Yoder, 406 U.S. at 215 (claim to exemption cannot be based on purcly secular considerations). See also United States v. Lee, 455 U.S. 252, 256-57 (1982) (preliminary imquiry in determining whether exemption is required is whether regulation intcrferes with free exercise rights). The validity of Sankirtan as a religious practice raises the question of what is "religion." The question is beyond the scope of this Note, but for some definitions of religion, see Davis v. Beason, 133 U.S. 333, 342 (1890); G. ALLPORT, ThE INDIVIDUAL AND HIS RELIGION vii, 142 (1962); Whitchead, Religion in the Making, in Alfred NorTH Whitehead: AN ANTHOlogy 472 (F. Northrop \& M. Gross eds. 1953).

100. See Lee, 455 U.S. at 257; Thomas, 450 U.S. at 716. For a discussion of the bona fides of Sankirtan as a religious practice, see, for example, International Soc'y for Krishna Consciousness, Inc. v. Bowen, 456 F. Supp. 437, $441-42$ (S.D. Ind. 1978), affd, 600 F.2d 667 (7th Cir.), cert. denied, 444 U.S. 963 (1979).

101. See Thomas, 450 U.S. at 715. See generally Marcus, The Forum of Conscience: Applying Standards Under the Free Exercise Clause, 1973 Duke L.J. 1217, 1250-51 (what constitutes an important rcligious practice is better decided by theologians than by judges). For an example of a court denying the bona fides of a religious practice, see United States v. Kuch, 288 F. Supp. 439, 443-45 (D.D.C. 1968) (religionists seeking exemption from federal drug laws were known as "Boo Hoos," and church motto was "Victory Over Horseshit").

102. See Heffron, 452 U.S. at 659 n.3 (Breiman, J., concurring in part and dissenting in part).

103. See generally Giannella, supra note 69, at 1419-23; Note, supra note 69, at 355 .

104. Thomas, 450 U.S. at 718. 
tion. ${ }^{105}$ The restriction in Sherbert $v$. Verner also resulted in indirect injury to a practice that was central to the religion. ${ }^{106}$ The rules that denied unemployment compensation created "unmistakable" pressure for the claimant to forgo her religious practice. ${ }^{107}$

Heffron shares factual elements with both of these cases. The degree of restriction in Heffron was substantial. Sankirtan was largely prohibited inside the fairground. ${ }^{108}$ Unlike the restriction in Sherbert and Thomas, the restriction here was direct. Moreover, Sankirtan is a practice central to the faith. ${ }^{109}$ As in Sherbert, the pressure to forgo the practice was great.

ISKCON's proof of a burden on religious practice by secular law, however, does not autoniatically entitle it to a free exercise exeniption. Minnesota could still assert some reason why an exemption should be denied. Any such justification nuust overcome two obstacles. First, the regulation must serve a state interest of the highest order. Only the "gravest abuses, endangering paramount [state] interests" can possibly justify restrictions in the "highly sensitive constitutional area" of religious practice. ${ }^{110}$ Similarly, in Yoder and Thomas, the Court required inore than a significant interest-the state had to show that the regulation served some interest "of the highest order." 111 The state in Heffron needed to show an extreniely important and compelling state interest.

The second obstacle is that the Court's examination of the state's interest is very narrow. The Court will not weigh the restriction on rehigious practice against a general state interest in enforcing its rules and regulations. The question has always been inore narrowly focused. In Sherbert, the proper question was whether granting the SeventhDay Adventist an exeinption froin the uneniployment coinpensation rules would render the statutory scheine unworkable. ${ }^{12}$ In Yoder, the

105. Id. at 711-12.

106. Sherbert, 374 U.S. at 404.

107. Id. at 403-04.

108. Heffron, 452 U.S. at $643-45,654-55$. The Court's decision in Heffron is likely to narrow the Krishnas' options for sites at which to practice Sankirtan. Compare, e.g., Fernandes v. Limmer, 663 F.2d 619, 634-35 (5th Cir. 1981) (invalidating ordinance restricting distribution and sohicitation at airport for overbreadth and vagueness), cert. dismissed, $103 \mathrm{~S}$. Ct. 5 (1982), and ISKCON, Inc. v. Schmidt, 523 F. Supp. 1303, 1308, 1310 (D. Md. 1981) (invalidating ordinance forbidding solicitations in parks without a permit), with, e.g., International Soc'y for Krishna Consciousness, Inc. v. New Jersey Sports \& Exposition Auth., 532 F. Supp. 1088 (D.N.J. 1981) (upholding ordinance blocking Krishna access to sports complex to practice Sankirtan), affd, 691 F.2d 155 (3d Cir. 1982) (following Heffron).

109. See, e.g., SRimad-BhagaVATAM, canto 5, ch. 19, at 260, quoted in Joint Appendix at A16, A-17, Heffron (No. 80-795) (performance of Sankirtan is the most exalted of all Krishna sacrifices).

110. Sherbert, 374 U.S. at 406 (quoting Thomas v. Collins, 323 U.S. 516, 530 (1945)).

111. Thomas, 450 U.S. at 718; Yoder, 406 U.S. at 215.

112. Sherbert, 374 U.S. at $408-09$. 
state sought to justify the requirement that the Amish attend high school by asserting its interest in compulsory education. ${ }^{113}$ The Court narrowed the issue of a proper state interest to an exammation of the stram the school system would sustam if an exemption were granted. ${ }^{114}$ Once the inquiry was so focused, the state could not justify the restriction. ${ }^{115}$ Similarly, in Thomas, the state attempted to justify its unemployment compensation scheme by asserting its interest in discouraging the widespread unemployment and the draining of the fund that would result if people were allowed to quit for personal reasons. ${ }^{116}$ Narrowmg the focus, the Court found no evidence in the record that "the number of people who find themselves in the predicanent of choosing between benefits and religious beliefs is large enough to create 'widespread unemployment.' "117 In all these cases, the state was not permitted to parade hypothetical claimants before the Court. ${ }^{118}$

In analyzing ISKCON's claim, the Court, consistent with Sherbert, Yoder and Thomas, should have narrowed the focus of its inquiry to the rehigious claimants whose rights were affected. Minnesota should not have been able to justify rule 6.05 by asserting its general interest in avoiding the congestion that would result if all orgamizations could roam the fairground distributimg literature and soliciting contributions. Rather, it should have been required to show that an exemption limited to valid religious claimants would result $\mathrm{m}$ an intolerably high degrce of disruption to pedestrian traffic flow. The relevant group should not have imcluded all persons who might want to solicit the public for personal, political, or other secular reasons, but only those who found themselves in "the predicament of choosing between . . . rehgious beliefs" and obeying the restrictive rule. ${ }^{119}$ Only ISKCON and perhaps a few religious groups compelled by their rehigions to engage im these activities were in such a predicament. ${ }^{120}$ The noncommercial groups

113. Yoder, 406 U.S. at 221.

114. Id.

115. Id. at 222-29.

116. Thomas, 450 U.S. at 718.

117. Id. at 719 .

118. This argument accords with the narrow rules of standing in free exereise cases. In free exercise challenges, only claimants alleging actual coercion by a regulation are considered "directly affected" for standing purposes. This rule is more narrow than general standing rules. See L. TRIBE, supra note 56, \& 3-19, at 87 n.38.

119. Thomas, 450 U.S. at 719.

120. The religious groups who seek to engage in these activities may be few in number. The Jehovah's Witnesses are one rehigious group commonly associated with such activities. See H. ABRAHAM, FREEDOM AND THE COURT 236-37 (4th ed. 1982).

The Court in Heffron listed some of the religious and other noncommercial organizations that rented booths at the fair. Heffron, 452 U.S. at 644 n.5. Only three or four of the religious groups conceivably could claim a religious duty to perform these activities, and it is likely that none of them would. 
listed by the Court were not. ${ }^{121}$

A more restrictive framing of the issues would have altered the result in Heffron. The Court should have asked whether Minnesota's interest in avoiding the congestion created by ISKCON members was so substantial that it justified a direct restriction making the fairground off limits for the performance of religious activities admittedly central to the members' faith. With the issue thus properly focused, the Court would have concluded that the restriction was not justified. Considering the small number of groups that could have made the religious claim, ${ }^{122}$ and the fact that all persons or groups could make speeclies, argue, and proselytize within the fairground, ${ }^{123}$ the additional congestion caused by exemptimg ISKCON members from rule 6.05 would not have been so overwhelming as to render the systein unworkable. Balanced against this limited disruption was the central importance of Sankirtan to the practice of Krishna and the direct prohibition on this practice imposed by the rule.

\section{b. Applying the free speech test.}

ISKCON had a better claim to rehef from rule 6.05 based on the free exercise clause than it did under the free speech clause. Free speech can be constitutionally limited by time, place, and maimer restrictions. In Heffron, the Court needed only to assess whether rule 6.05 was a reasonable limitation. Five factors were considered: whether the rule was content based; ${ }^{124}$ whether the rule gave discretion to an official and thereby allowed discriminatory application; ${ }^{125}$ whether ample alternative channels were left open for dissemination of the excluded information; ${ }^{126}$ whether the rule served some valid state mterest; $^{127}$ and whether alternative means less restrictive of first amendment rights were available to serve those interests. ${ }^{128}$ The first three requirements were met. Since the rule applied uniformly to all groups, it was not content based. ${ }^{129}$ The rule was not susceptible to arbitrary and discriminatory enforcement because booths were assigned on a first-come-first-served basis. ${ }^{130}$ Lastly, ISKCON had alter-

121. Heffron, 452 U.S. at 644 n.5.

122. See supra note 120.

123. Heffron, 452 U.S. at 661 (Brennan, J., concurring in part and dissenting in part).

124. Id. at 648 (opinion of the Court).

125. Id. at 649.

126. Id. at 654 .

127. Id. at 649.

128. Id. at 654. For a helpful discussion of the application of least restrictive means analysis to free exercise cases, see Merel, The Protection of Individual Choice: $A$ Consistent Understanding of Religion Under the First Amendment, 45 U. CHI. L. REv. 805, 817-18 (1978).

129. Heffron, 452 U.S. at 649.

130. Id. 
native channels of communications. ${ }^{131}$ Its members could distribute and sell hiterature and solicit contributions outside the fairgrounds. They could also attract the public, in a limited fashion, from their assigned booth.

The Court's treatment of the fourtl requirement, that the regulation serve some significant state interest, clarified the differences between the speech and rehgion tests. In the speecl context, the claim is not for an exeinption froin the regulation; claimants may challenge the facial validity of the ordmance. ${ }^{132}$ ISKCON challenged rule 6.05 both on its face and as applied. ${ }^{133}$ On the basis of the speech test, the Court was correct not to distmguish between ISKCON and other groups with ideological, political, and social inessages. Arguably, the state legitiinately offered as a justification for rule 6.05 the potentially severe congestion that would result from allowing all groups at the fair to distribute and solicit freely. Indeed, the Court concluded the congestion would be severe enough to justify the rule. ${ }^{134}$ The same is not true, lowever, of ISKCON's claim for an exemption based on the free exercise clause. Only ISKCON, and possibly a few other religious groups, are compelled by their religions to solicit donations and distribute literature as fervently as Sankirtan demands. ${ }^{135}$ The congestion created by an exemption for thein would be minimal.

The final inquiry is whether less restrictive means exist which could achieve rule 6.05 crowd-reduction purposes. Since the speech claim requires ISKCON to be considered along with all other groups, it is unlikely that alternative strategies such as penalizing disorderly conduct or putting inore narrowly drawn limits on the novement of solicitors would be effective. ${ }^{136}$ As the Court pointed out, the greater the number of groups allowed to engage in these activities, the less likely the alternatives are to succeed. ${ }^{137}$ Since the relevant groups are far fewer in the free exercise exemption case than in the speech case, alternative means are more likely to be feasible in the former context.

A religious group is more likely to succeed with a free exercise claim than in an action based on the free speech clause. Under the rehigion test, the fact that Sankirtan is central to ISKCON substantially strengthens ISKCON's claim. More importantly, the test for religious interference focuses on a mucli smaller group. State imterests based on

131. Id. at $654-55$.

132. See supra note 96 and accompanying text.

133. Heffron, 452 U.S. at 644.

134. Id. at $653-54$.

135. See supra note 120 and accompanying text.

136. Whether alternative means less restrictive of first amendment rights are available is also an issue in exemption cases. See, e.g., Sherbert, 374 U.S. at 407; Merel, supra note 128, at 818.

137. Heffron, 452 U.S. at 654. 
crowd control would be weakened by these facts. The fundamentally different issues of speech and religion should have been analyzed separately. An analysis of ISKCON's claimed exemption from rule 6.05 under the free exercise clause would have led the Court to conclude that the threat of congestion was imsufficient to justify the restriction. The Court's use of free speech analysis was fatal to ISKCON's rightsit denied ISKCON a fair resolution of its claim.

\section{CONCLUSION}

The free exercise clause and the free speech clause protect very different rights. In Heffron, the Court ignored this fundamental difference and equated rehion and speech. Given the precedents of Sherbert, Yoder and Thomas, which make a free exercise claim to an exemption fronı a statute or rule stronger than a free speech claim, the Court wrongly and unsatisfactorily adjudicated the claim in Heffron.

Free exercise of rehigion and free speech are fundamental liberties; a claim that they can be restricted inerits careful scrutimy. When a claim involves both free exercise of rehion and free speech, the separate hiberties cannot be treated identically and cannot be analyzed only as a rcstriction on speech. The Court should use the free speech test to analyze a claim that free speech rights are violated, and the test enunciated in Sherbert, Yoder, and Thomas to analyze a claim that the right to free exercise of rehgion is violated. Only this separate analysis will satisfy the requirements of careful scrutiny, respect the differences between free speech and free exercise of rehgion, and protect each fundainental liberty.

Ronald Baxt Turovsky*

* A.B. 1979, University of California, Berkeley; M.S. 1980, Columbia University; thirdyear student, Boalt Hall School of Law, University of California, Berkeley. 